\title{
The post partum mare
}

\author{
Terttu Katila' and Tiina Reilas ${ }^{2}$ \\ 'University of Helsinki, Department of Clinical Veterinary Sciences, Saari Unit, Finland; ${ }^{2}$ Agricultural Research Centre, Equine Research, Ypäjä, Finland
}

\begin{abstract}
Summary
Because of the long gestation period, a mare should conceive soon after foaling in order to foal every year. Although lactation is high and uterine involution incomplete, the mare is able to conceive during the first post partum (p.p.) oestrus. Normal delivery causes little damage to the uterine epithelium. The numerous microcaruncles disappear rapidly by degeneration and resorption. A tremendous decrease in uterine size takes place after foaling, particularly during the first week after foaling. By 3 weeks p.p. the uterus has returned to the pregravid size. For several days following parturition the uterus is extremely firm upon transrectal palpation, probably because of the extensive p.p. oedema. Intrauterine fluid collections are largest 1 to 2 d p.p. and decrease gradually between days 4 and 7 ; no fluid is normally detected after day 16 . The process of bacterial elimination is not completed in all mares during the foal heat, but the incidence of positive cultures is much lower than shortly after foaling. Neutrophils are a common finding in uterine swabs $<6$ d p.p., and some mares show low numbers of neutrophils still during the foal heat. The uterine environment changes markedly even after the first p.p. ovulation. After day 16, protein and enzyme levels in uterine lavage fluid of p.p. mares had decreased to normal levels, showing that the secretory function had been restored to the pregravid state. Trypsin inhibitor capacity, lysozyme levels and neutrophil numbers in uterine lavage fluid during foal heat tended to be higher in mares from which no embryos were recovered, suggesting that a persisting inflammation at the end of foal heat may be the best explanation for lowered pregnancy rates. The presence of ultrasonically detectable intrauterine fluid has also been show to decrease foal heat pregnancy rates.
\end{abstract}

Keywords: $\quad$ horse, uterus, involution, inflammation, foal heat

\section{Die postpartale Stute}

Stuten sollten auf Grund ihrer langen Trächtigkeitsdaver kurz nach der Abfohlung wieder aufnehmen, um jedes Jahr ein Fohlen auf die Welt zu bringen. Trotz der hohen Milchleistung und der unvollständigen Involution des Uterus ist die Stute in der Lage, während des ersten Östrus post partum (p.p.) zu konzipieren. Eine normale Geburt verursacht nur geringe Läsionen am uterinen Epithel. Die zahlreichen Mikrokarunkeln werden schnell durch Degeneration und Resorption eliminiert. Nach der Abfohlung verkleinert sich der Uterus erheblich, vor allem in der ersten Woche nach der Geburt. Innerhalb von drei Wochen p.p. erreicht die Gebärmutter wieder ihre prägravide Größe. Nach der Abfohlung weist der Uterus für mehrere Tage bei der rektalen Palpation eine sehr feste Konsistenz auf, wahrscheinlich auf Grund des hochgradigen postpartalen Ödems. Intrauterine Flüssigkeitsansammlungen sind 1-2 Tage p.p. am stärksten ausgeprägt, sie nehmen zwischen den Tagen 4 und 7 graduell ab und nach dem Tag 16 ist normalerweise keine Flüssigkeit mehr vorhanden. Nicht bei allen Stuten ist die Elimination von Bakterien während der Fohlenrosse vollständig abgeschlossen, aber positive Befunde sind wesentlich seltener als kurz nach der Geburt. Bis zum 6. Tag p.p. werden häufig neutrophile Granulozyten zytologisch nachgewiesen, einige Stuten weisen auch noch in der Fohlenrosse geringgradig neutrophile Granulozyten auf. Das uterine Milieu verändert sich auch noch nach der ersten postpartalen Ovulation sehr. Nach dem 16. Tag sind die Protein- und Enzymkonzentrationen in der uterinen Spülflüssigkeit postpartaler Stuten auf normale Werte gesunken. Dies zeigt, dass die sekretorische Funktion ihren prägraviden Status wieder erlangt hat. Die Kapazität des Trypsininhibitors, Lysozym-Konzentrationen und die Anzahl neutrophiler Granulozyten in der uterinen Spülflüssigkeit ist in der Fohlenrosse bei den Stuten höher, von denen keine Embryonen gewonnen werden konnten. Dies spricht dafür, dass eine persistierende Entzündung am Ende der Fohlenrosse die beste Erklärung für niedrigere Trächtigkeitsraten ist. Es wurde zudem gezeigt, dass ultrasonographisch feststellbare intrauterine Flüssigkeitsansammlungen die Trächtigkeitsaussicht während der Fohlenrosse senken.

Schlüsselwörter: Pferd, Uterus, Involution, Entzündung, Fohlenrosse

\section{Introduction}

Because of the long gestation, 11 months, the mare should conceive within a month after the previous parturition to foal every year. The first post partum (p.p.) oestrus, commonly called as foal heat, has some unique features as compared to other species. The onset is very early, the heat is visible despite the absence of a preceding progesterone phase, it is an ovulatory oestrus, and the uterine involution has not been completed.

It is amazing that the mare is able to conceive as early as only a week after parturition. However, the pregnancy rates in foal heat have usually been lower than in subsequent oestruses, but we have no practical way of diagnosing which mares are ready to be bred in foal heat and which ones are not.

\section{Involution of the uterus}

When the villous epitheliochorial placenta separates at the maternal-foetal interface, the uterine epithelium stays relatively undamaged. The numerous tiny microcaruncles disappear rapidly by degeneration and resorption. Gradually the structure disappears and only cell-dense stromal areas can be seen. In biopsy specimens taken 10 and 15 days p.p. the former microcaruncles were detectable only by the occurrence of siderophages and lymphocytes (Gygax et al. 1979; Bailey and Bristol 1983; Katila 1988).

Uterine glands are numerous, evenly distributed and dilated, and their lumen contains various amounts of cellular debris $<2$ days p.p. Siderophages are present in large numbers around 
the glands and in the glandular epithelium. By day 15, almost all glands have returned to the pregravid size (Bailey and Bristol 1983; Katila 1988).

\section{Bacteriology}

Streptococci and coliforms are the most frequently cultured organisms from uterine swabs of p.p. mares. E. coli is the most commonly isolated microorganism early p.p., but is replaced by streptococci during the advancing involution (König 1975; Gygax et al. 1979; Katila et al. 1988b).

The incidence of bacteriologically positive swabs 1 to 2 days p.p. has often been lower (around 20 to $40 \%$ of mares) than a couple of days later, 3 to 6 days p.p. (70 to 90\%) (König 1975; Gygax et al. 1979; Katila et al. 1988b). Management of foaling mares, environment and events during foaling influence the degree of bacterial contamination. Mares with puerperal disturbances - dystocia or retained placenta - had more bacterial growth on days 3, 6, and 9 p.p. than mares having normal deliveries (Glatzel and Belz 1995). Although uterine swabs obtained from mares in foal heat are often bacteriologically positive, the incidence of positive samples is lower than shortly after foaling (König 1975; Gygax et al. 1979; Bailey and Bristol 1983). If only samples yielding heavy or moderate bacterial growth are considered as meaningful, the number of positive mares in foal heat is small (Katila et al. 1988b; Sertich and Watson 1992). In all these studies the same mares had been sampled on several consecutive days. Therefore, uterine swabbing may have increased contamination of the uterus.

\section{Leukocytes}

Polymorphonuclear leukocytes (PMN) were a common finding in uterine swabs < 6 days p.p. (Katila et al. 1988b). During foal heat approximately one third of the mares showed no PMNs in the cytological examination, one third had only a few PMNs and one third of the mares had a moderate to high amount of PMNs (Shideler et al. 1987; Katila et al. 1988b; Huhtinen et al. 1996). Mares that had had puerperal disturbances, particularly retained placenta, showed high numbers of PMNs in lochial secretes 3 to 6 days p.p. (Belz and Glatzel 1995).

An agreement of $86 \%$ between the presence of bacteria and PMNs in samples of p.p. mares has been reported by Katila et al. (1988b). PMNs are needed to clear bacterial infections introduced during and immediately after parturition. Leukocytes are needed also to destroy microcaruncles (Gygax et al. 1979; Katila 1988) which explains why many p.p. mares exhibit PMNs but no bacteria in uterine swabs (Katila et al. 1988b). Another reason for the presence of PMNs without bacteria is that bacteria have already been eliminated but signs of the inflammatory process are still there. The best explanation for the presence of bacteria without PMNs is contamination during sampling.

Cytological examination of uterine swabs is a quick method to assess the presence and degree of acute inflammation in uterine lumen and on the surface of the luminal epithelium, but uterine biopsy specimen provides a deeper view. Biopsy specimen obtained 1 to 2 days p.p. showed predominantly PMN cells concentrated in the stratum compactum, particularly around the microcaruncles. By day 5 lymphocytes appeared and replaced PMNs. Periglandular and-vascular lymphocytic infiltrations were a common finding in biopsy specimen obtained 10 days p.p. (Shideler et al. 1987; Katila 1988).

\section{Uterine size and tone}

A tremendous change in uterine size takes place after foaling, particularly during the first week after foaling as assessed by rectal palpation (Gygax et al. 1979; Katila et al. 1988a). Transrectal ultrasonography allows more accurate measurements of the diameter of the uterine horns than palpation. Using ultrasonography it has been shown that after 3 weeks the uterus has been returned to the pregravid size (McKinnon et al. 1988; Sertich and Watson 1992).

For several days following parturition the uterus is extremely firm upon transrectal palpation, particularly during the first week (Katila et al. 1988a; Griffin and Ginther 1991). This is probably due to the extensive p.p. oedema. Prostaglandin $\mathrm{F}_{2 \alpha}$ release as measured by its plasma metabolite concentration is high immediately after foaling, but returns to the baseline within 3 days (Sertich and Watson 1992). Ultrasonically detectable uterine contractility has been very low between the day of parturition and the first ovulation (Griffin and Ginther 1991). Both of these findings are somewhat surprising, since one would expect high contractile activity, which would facilitate emptying and cleansing of the uterus and involution.

\section{Uterine fluid}

The possibility to collect uterine fluid by tampons or by uterine lavage allows us to determine concentrations and amounts of components of uterine fluid and to quantitate numbers of bacteria and PMNs. From uterine lavage fluids collected 1 to 4 days p.p., 58\% were bacteriologically positive. Lavage fluids obtained 1 to 10 days p.p. showed PMNs in 63\% of mares, but lavage fluids collected as late as 12 to 28 days p.p. were still positive for PMNs in $22 \%$ of mares (Reilas and Katila, in print). Total protein, lysozyme, $\beta$-glucuronidase (B-Gase), N-acetyl$\beta$-D-glucosaminidase (NAGase), acid phosphatase, and plasmin levels and trypsin-inhibitor capacity (TIC) were high for 2 to 6 days after parturition and then declined to low levels by day 16 p.p. Except for TIC and plasmin, the p.p. levels were as high as after experimental bacterial inoculation. TIC and plasmin activity as well as lysozyme levels seemed to be associated with high PMN numbers and inflammation in p.p. mares. After day 16 p.p., protein and enzyme levels were at the same level as in normal cyclic dioestrous mares, showing that the secretory function of the endometrium has presumably been restored to the pregravid state (Reilas and Katila, in print).

\section{Foal heat}

Reported mean lengths of the interval from parturition to the start of the first p.p. oestrus are generally given as 7 to 9 days, and the majority of mares begins oestrus within 5 to 12 days. The first ovulation usually takes place 9 to $12 \mathrm{~d}$ p.p., but is 
dependent on the time of the year. For Thoroughbreds in Kentucky the average interval to first ovulation was $10.2 \pm 2.4$ days. By day 9 p.p., $43 \%$ of mares had ovulated, $93 \%$ by day 15 , and $97 \%$ by day 20 p.p. (Loy 1980).

Pregnancy rate and pregnancy loss rate

Pregnancy rates of mares bred in foal heat have been reported to be more than 10 times lower than pregnancy rates at subsequent oestrous periods. It is natural that mares ovulating later in foal heat have higher pregnancy rates than mares ovulating early. The pregnancy rate of mares ovulating $>11$ days p.p. was $59 \%$ as compared to the $45 \%$ pregnancy rate of mares ovulating $<11$ days (Loy 1980). In different stud farms pregnancy rates vary a lot, and this can be explained by managemental differences (Loy 1980; Lenz 1986). Because of improved management and veterinary skills and the use of artificial insemination and ultrasonography the pregnancy rates of all mares have increased considerably. Recently, high pregnancy rates have been reported also for mares bred in foal heat (Camillo et al. 1997: 72\%; Arrott et al. 1994: 82\%).

Merkt and Günzel (1979) reported a higher pregnancy loss rate for lactating mares than for non-lactating mares: $17 \%$ vs. $6 \%$. In many other studies the pregnancy loss rates of mares conceiving in foal heat as compared to foaling mares that conceived in subsequent oestruses have not been significantly different (Lieux 1980: 16\% vs. 14\%; Loy 1980: 13\% vs. 12\%). On the other hand, when risk of early embryonic loss was evaluated using the logistic regression model, mares bred on foal-heat were 1.9 times more likely to experience early embryonic mortality (Meyers et al. 1990). Furthermore, abortion rate has been reported to be significantly higher for foaling mares bred $<16$ days p.p. as compared to mares bred $>16$ days p.p.: $11.1 \%$ vs. $7.6 \%$ (Chevalier-Clément 1989).

\section{Breeding in foal heat}

The short breeding season and the long gestation length impose pressures to breed in foal heat. The lowered pregnancy rate, the tendency to increased pregnancy loss, and the risks in the transport of a young foal are the most important reasons for postponing breeding. It is important to note that the time from foaling to conception was in average 18.5 days shorter in mares bred in foal heat as compared to mares bred first in the $2^{\text {nd }} p . p$. oestrus (Loy 1980). It is clear that if any complications have occurred during or after parturition breeding in foal heat should be withheld. It has been shown that breeding in foal heat does not worsen the mare's chances of conceiving in the next oestrus (Lieux 1980), but sometimes it would be of advantage to breed only mares which are very likely to conceive. With the increased use of modern, but more expensive breeding techniques, such as frozen semen, imported fresh semen, or embryo transfers, this has become more important.

It seems natural to expect that the size of the uterus would indicate the rate of uterine involution and, thus, the probability of the mare to conceive. Experienced practitioners have shown that this is not the case (Loy 1980; Lenz 1986). None of the following parameters examined - uterine size, tone and contents; palpability of endometrial folds; amount and character of vaginal contents; oedema and colour of portio vaginalis - were correlated with the outcome of foal heat insemination (Katila et al. 1988a). The presence of bacteria or PMNs in uterine swabs had no correlation with foal heat pregnancy rate (Katila et al. 1988b) or embryo recovery rate (Huhtinen et al. 1996). Mares who had large amounts of PMNs in uterine biopsies on the $5^{\text {th }}$ day p.p. showed significantly $(p<0.05)$ decreased foal heat pregnancy rates (Katila et al. 1988b), but processing of biopsy samples takes too long to be a routine method in the practice. TIC, lysozyme levels and PMN numbers in uterine lavage fluids obtained after the detection of the first p.p. ovulation tended to be higher in mares that did not have embryos 7 or 8 days later. The results suggest that inflammation persisting still at the end of foal heat could be the best explanation for low pregnancy rates (Reilas et al. 2000).

Transrectal ultrasonography is useful in the evaluation of foal heat mares, as shown by McKinnon et al. (1988). Fewer $(p<0.005)$ mares became pregnant if they were bred when uterine fluid was detected during foal heat (33\%), compared with mares bred when fluid was not detected (84\%). The uteri of mares with i.u. fluid accumulations during breeding were not larger than uteri of the mares that did not have fluid. There was no correlation between change in uterine size (from ovulation to $29 / 31$ days p.p.) and pregnancy rates.

\section{Literature}

Arrott, C., Macpherson, M., Blanchard, T., Varner, D., Thompson, J., Simpson, B., Bruemmer, J., Vogelsang, S., Fernandez, M., Fleet, T. and Burns, P. (1994): Biodegradable estradiol microspheres do not affect uterine involution or characteristics of postpartum estrus in mares. Theriogenology 42, 371-384.

Bailey, J. V. and Bristol, F. M. (1983): Uterine involution in the mare after induced parturition. Am. J. Vet. Res. 44, 793-797.

Belz, J. P. and Glatzel, P. S. (1995): Fruchtbarkeit bei Stuten nach gestörtem bzw. ungestörtem Puerperium. Aussagekraft histologischer und zytologischer Untersuchungen (Fertility in mares after disturbed or undisturbed puerperal periods: Significance of histological and cytological examinations of the uterus). Tierärztl. Prax. 23, 267-272.

Camillo, F., Marmorini, P., Romagnoli, S., Vannozzi, I. and Bagliacca, M. (1997): Fertility at the first post partum estrous compared with fertility at the following estrous cycles in foaling mares and with fertility in nonfoaling mares. J. Equine Vet. Sci. 17, 612-616.

Chevalier-Clément, F. (1989): Pregnancy loss in the mare. Anim. Reprod. Sci. 20, 231-244.

Glatzel, P. S. and Belz, J. P. (1995): Fruchtbarkeit bei Stuten nach gestörtem bzw. ungestörtem Puerperium. Aussagekraft klinischer, mikrobiologischer und hormonanalytischer Untersuchungen (Fertility in mares after disturbed or undisturbed puerperal periods: Significance of clinical, microbiological and hormonal examinations). Berl. Münch. Tierärztl. Wschr. 108, 367-372.

Griffin, P. G. and Ginther, O. J. (1991): Uterine morphology and function in postpartum mares. Equine Vet. Sci. 11, 330-339.

Gygax, A. P., Ganjam, V. K. and Kenney, R. M. (1979): Clinical, microbiological and histological changes associated with uterine involution in the mare. J. Reprod. Fert., Suppl. 27, 571-578.

Huhtinen, M., Reilas, T. and Katila, T. (1996): Recovery rate and quality of embryos from mares inseminated at the first post-partum oestrus. Acta vet. Scand. 37, 343-350.

Katila, T. (1988): Histology of the post partum equine uterus as determined by endometrial biopsies. Acta vet. Scand. 29, 173-180. 
Katila, T., Koskinen, E. and Oijala, M. (1988a): Evaluation of the post partum mare in relation to foal heat breeding. I. Rectal palpation, vaginoscopy and ultrasound scanning. J. Vet. Med. 35, 92-100.

Katila, T., Koskinen, E., Oijala, M. and Parviainen, P. (1988b): Evaluation of the post partum mare in relation to foal heat breeding. II. Uterine swabbing and biopsies. J. Vet. Med. 35, 331-339.

König, K. (1975): Klinische und bakteriologische Untersuchung des Genitaltraktes der Stute während des Puerperiums, Vergleich der Untersuchungsergebnisse hinsichtlich des Alters und der weiteren Fruchtbarkeit der Stuten sowie Beurteilung der Besamungstauglichkeit der Fohlenrosse aus bakteriologischer Sicht (Clinical and bacteriological examination of the genital tract of the mare during the puerperium with special reference to the age and fertility of the mares and evaluation of fertility in the foal heat from a bacteriological point of view). Dissertation, Hannover.

Lenz, T. R.. (1986): The practitioner's approach to foal heat breeding. Proc. Ann. Meeting Soc. Theriogenology, 111-119.

Lieux, P. (1980): Comparative results of breeding on first and second post-foaling heat periods. Proc. $26^{\text {th }}$ Ann. Conv. Am. Ass. Equine Practitioners, 129-132.

Loy, R. G. (1980): Characteristics of postpartum reproduction in mares. Vet. Clin. NA: Large Animal Practice 2 (2), 345-359.

McKinnon, A. O., Squires, E. L., Harrison, L. A., Blach, E. L. and Shideler, R. K. (1988): Ultrasonographic studies on the reproductive tract of mares after parturition: Effect of involution and uterine fluid on pregnancy rates in mares with normal and delayed first postpartum ovulatory cycles. J. Am. Vet. Med. Ass. 192, 350-353.
Merkt, H. and Günzel, A.-R. (1979); A survey of early pregnancy losses in West German Thoroughbred mares. Equine Vet. J. 1 1, 256-258.

Meyers, P. J., Bonnett, B. N. and McKee, S. L. (1990): An epidemiological approach to the investigation of early embryonic mortality in mares. Proc. Ann. Meet. Soc. Theriogenology, 152-168.

Reilas, T., Huhtinen, M., Oksanen, M. and Katila, T. (2000): Relationship between embryo recovery rate and uterine lavage fluid composition in postpartum mares. Reprod. Nutr. Dev. 40, 383-391.

Reilas, T. and Katila, T. (in print): Proteins and enzymes in uterine lavage fluid of postpartum and nonparturient mares. Reprod. Dom. Anim.

Sertich, P. L. and Watson, E. D. (1992): Plasma concentrations of 13, 14-dihydro-15-ketoprostaglandin $F_{2 \alpha}$ in mares during uterine involution. J. Am. Vet. Med. Ass. 201, 434-437.

Shideler, R. K., McChesney, A. E., Squires, E. L. and Osborne, M. (1987): Effect of uterine lavage on clinical and laboratory parameters in postpartum mares. Equine Pract. 9, 20-26.

Prof. Terttu Katila

Pohjoinen Pikatie 800

Fl-04920 Saarentaus

Finland

Tel.: 00358-19-5295303

Fax.: 00358-19-6851181

Tkatila@saari.vetmed.helsinki.fi 
